\title{
Teologiekroniek - Totius se vertaling van die Psalms in die Bybel en sy beryming daavan
}

T T Cloete

(PU vir $\mathrm{CHO})$

\section{ABSTRACT}

The Psalms in the first Bible translation and its versification by Totius

The versification of the Psalms in Afrikaans by Totius is regarded as a part of Afrikaans literature. Its publication and the first edition of the Bible in Afrikaans in the thirties both coincided with a renewal in Afrikaans literature. In this article the relation between the versification of the Psalms and the Biblical Psalms is investigated.

'n Taal word nie net gemaak en verfyn in literêre kunswerke nie, dit word minstens net so goed gebrei en uitgebrei op die terreine van die wetenskappe of tegnologie, die joernalistiek, die opvoedkunde, die ekonomie, die regte en die teologie. Toe die Afrikaanse Ou Vertaling van die Bybel (die AOV) in 1933 veskyn het, was die Afrikaanse prosakuns en digkuns bloedjonk, en die Afrikaans van die AOV het net soos die literêre werke van destyds 'n belangrike bydrae tot ons taal geword. Trouens, die AOV verskyn in dieselfde tyd as die vroeë literêre werke van die sogenaamde Dertigers en is selfs deel van die literêre oplewing van daardie tyd.

Die AOV het baie gehelp om die Afrikaans van vandag te maak wat dit is. Daardie prosa het van ons beste literatuurskrywers help slyp, prosaïste en digters. As mens N P van Wyk Louw lees, hoor jy die taal en beelde van die AOV duidelik in sy gedigte. Dit geld ook in 'n mindere mate vir W E G Louw en ander.

Die standaard van Totius se Afrikaans in die AOV en die goeie beeld wat dit gee van die Afrikaans van daardie tyd, is die een kant van die saak. Die ander kant is dat mens nie dieselfde van die Afrikaans van die Totiusberyming van die Psalms (die Tb) kan sê nie. Die Tb verskyn min of meer in dieselfde tyd as die AOV (1936).

Die Psalms soos Totius dit in die Bybel vertaal het, is uiteraard in ' $n$ hoë mate digterlik, maar dit is 'n sober liriek, in hoë mate tewens spreektalig.

Vanwaar dan die verskil tussen Totius se Afrikaans in die AOV en in die Tb? Dit is hoofsaaklik daaraan toe te skryf dat Totius in sy Psalmberyming in 'n baie groot mate gesteun het op die Nederlandse beryming van 1773 (die N1773), en op ander ou Nederlandse berymings, in die besonder soos hy dit gevind het in die Psalmbundel van $\mathbf{J}$ 
van Elring, waarin Nederlandse berymings van die vroegste tye af opgeneem is (Die N1773 is nie lank na die verskyning van die Tb nie in Nederlands self vervang deur ' $n$ ander beryming [Die Interkerklike Stichting 1961]). Waar Totius in sy prosavertaling van die Psalms in die Bybel klaarblyklik baie vertalings in verskeie tale geraadpleeg het, het hy hom in die beryming van die Psalms hoofsaaklik op bogenoemde twee voorbeelde verlaat.

Die N1773 was tot met die verskyning van die Tb in die Afrikaanse kerke in gebruik. Miskien het Totius hom bewustelik, uit vrye wil of as opdrag, so na moontlik aan die destyds bekende Nederlandse berymings gehou.

Hy erken in sy Voorwoord tot die $\mathrm{Tb}$ dat hy soms direk uit die Nederlands oorgeneem het, maar hy het aansienlik méér, soms in versteekte vorm, en baie meer dikwels direk, woord vir woord, oorgeneem as wat hy aandui.

Baie van die onnatuurlike, vernederlandste of argaïese Afrikaans in die $\mathrm{Tb}$ is afgedwing deur die rym. Dit sluit in woorde soos prysgegewe, gadeslaan, alom, ontwring, sponde, teenpartyders, telg, kommernis, waardy, onendig, weggedaan, wig (vir kind), vervoegings soos ten troon of ter ore, ongewone meervoude soos teëspoede... daar is talle voorbeelde hiervan. Dit is ' $n$ soort taal wat nie in die prosa van Totius se Bybelvertalings voorkom nie en ook nie in die prosa van ander Afrikaanse skrywers van daardie tyd nie - selfs nie in die werk van Van Melle met sy Hollandse herkoms nie.

Daar is ook talle argaïsmes en Nederlandismes in die $\mathrm{T} \overrightarrow{\mathrm{b}}$ wat nie deur die rym afgedwing is nie maar deur die algemene invloed wat die Nederlandse berymings op Totius gehad het, woorde soos send, snode, onspoed (vir teenspsoed), send (vir stuur)... die voorbeelde hiervan is ook talryk.

Totius het in die vertaling van die Psalms in die AOV sekerlik ook gekyk na Nederlandse vertalings (sekerlik ook die Statevertaling), maar in die AOV het hy, anders as in die Tb, onafhanklik van Nederlands sy gang gegaan. Ten spyte van sy Nederlandse voorbeelde het sy Afrikaans in die AOV 'n eie klank en karakter behou, hoe na Afrikaans uiteraard ook aan Nederlands staan. $\mathrm{Al}$ is daar ' $\mathrm{n}$ noue verband tussen Afrikaans en Nederlands en al lyk die Afrikaans van die AOV in sy beeldspraak, metafore, ens. dikwels op die Nederlandse vertalings, is dit soms net ' $n$ enkele woord van Totius wat ' $n$ eg-Afrikaanse klank aan sy vertaling gee. Psalm 109:23 lui: Ek gaan heen soos 'n skaduwee as dit lank word; ek is afgeskud soos 'n sprinkaan wat nie voorkom in die Nederlandse vertalings wat ek graadpleeg het nie en waar, soos in die Afrikaanse Nuwe Vertaling (ANV), van "weggevee" gepraat word.

Daar is uiteraard ' $n$ taamlike verskil tussen die taal van ' $n$ gedig 
en dié van 'n prosawerk. Hierdie natuurlike verskil is egter nie 'n verklaring vir Totius se in 'n groot mate onnatuurlike Afrikaans in die $\mathrm{Tb}$ in vergelyking met die sober en tog beeldryke taal van die AOV sover dit veral die Psalms betref nie. Daar is baie poësie in die Psalms soos dit in die Bybel deur Totius vertaal is, en mens durf beweer dat sekere Psalms in die AOV meer poëties is as in die Tb. Veral die Pelgrimsliedere (120-134) is vol poësie, of ons kan ook sê: hulle is pragtige prosagedigte. Dink ook aan Psalm 139, onder andere. Dit is, terloops, ook verkeerd om te redeneer dat die gedigte van 'n literatuur meer groeikrag as die prosa van daardie literatuur het.

'n Mens kan aan Psalm 117, die kortste Psalm in die Bybel, sien hoe Totius nie sy eie Afrikaanse voorbeeld in die AOV gevolg het nie maar die Nederlandse beryming in die N1773. So lyk Psalm 117 in die AOV:

1. Loof die Here, alle nasies! Prys Hom, alle volke! 2. Want sy goedertierenheid is geweldig oor ons, en die trou van die Here is tot in ewigheid. Halleluja!

So lyk dieselfde Psalm in die Tb:

Loof, loof die Heer, o heidendom!

O volke, prys sy Naam alom!

Sy goedheid is in nood en dood

vir ons, sy volk, oneindig groot.

Sy waarheid wankel nimmermeer.

Sing, halleluja, sing sy eer!

So lyk Totius se Nederlandse voorbeeld:

Loof, loof den Heer, gij heidendom!

Gij volken, prijst zijn Naam alom!

Zijn goedheid is in nood en dood voor ons, zijn volk, oneindig groot:

zijn waarheid wankelt nimmermeer.

Zijngt, halleluja, zingt zijn eer!

Totius het, in navolging van sy voorbeeld, in Psalm 117 nie alleen in sy woordeskat afgewyk van die AOV nie maar ook in sy byvulling van die teks (vergelyk daardie "heidendom" of "nood en dood") en in sy begrippe: Die goedertierenheid en trou, soos dit in die AOV staan, 
word in die ANV vertaal met liefde en trou. In die Tb word dit vertaal met goedheid en waarheid, want dit is soos Totius dit in die N1773 kry. Die waarheid in plaas van die trou van God kom klaarblyklik uit die N1773, al kom dit ook in ander vertalings voor. Psalm 117 is in die $\mathrm{Tb}$ 'n woord - en omtrent klankgetroue oorheveling uit die N1773.

Ook in Psalm 105 van die $\mathrm{Tb}$, onder baie ander dergelike voorbeelde, het Totius hom besonder getrou aan die N1773 gehou. Tot die aantal strofes is dieselfde (24 - dit is ' $n$ lang Psalm). Totius het in sy Bybelvertaling nie geskroom om die eenvoudige alledaagse taal te gebruik nie en hy het in die prosa van die AOV vir pront Afrikaans gedoen wat sy tydgenoot Leipoldt in die Afrikaanse digkuns daarvoor gedoen het. In sy berymings het hy egter waarskynlik gedink sulke taal pas nie in die (gewyde) liriek nie. Waar die Egiptiese plae in die AOV beskryf word, staan daar:

30. Hulle land het gewemel van paddas, in die kamers van hulle konings.

In die $\mathrm{Tb}$ staan (str. 17):

Die kikvors kruip in al hul wonings

In die N1773 staan (weer in str. 17):

een machtig heir van vorsen komen

Paddas pas ritmies-metries net so goed in die vers as kikvors, wat in Afrikaans in Totius se tyd lankal in onbruik geraak het, maar hy het die meer "verhewe" Nederlandse woord gekies. Vers 34 van die AOV is pure en pragtige Afrikaans:

en daar het sprinkane gekom en voetgangers sonder getal.

In die $\mathrm{Tb}$ (strofe 19) lees mens:

Nog twis God met die wederstrewers:

nou kom die sprinkaan en die kewers

want in die N1773 staan in die gelyk genommerde strofe (19!)

De sprinkhaan en de kever kwamen gelijk een talloos leger samen. 
Ridderbos (1994) vertaal vers 34 met "sprinkhanen" en "hippers", Ida Gerhardt (1994) vertaal dit met "sprinkhanen" en "kaalvreters". Die ANV praat van sprinkane. Ek vind ook in my Engelse vertalings niks van kewers nie. Die kewers kry Totius dus waarskynlik weer van die N1773 (al staan dit daar nie eers in die rym nie).

Ek het hierbo daarop gewys dat hoewel die Psalms uiteraard liries is, is dit ' $n$ sober liriek en tewens spreektalig en pront, soos Psalm 38, wat geskryf is in van Totius se beste prosa in die AOV, en dit is een van daardie Psalms wat die lyding en sondigheid van die mens in beelde en metafore van byna die hele liggaam beskryf, en veral vers 6 is baie direk:

6. My wonde stink, hulle dra vanweë my dwaasheid

In sy beryming van Psalm 38 het Totius nie getrou gebly aan die woordeskat in die AOV nie maar plek-plek eerder die Nederlandse beryming gevolg soos hy dit in Van Elring gevind het. Kosbare dinge van die lyflike taal van die AOV is nie opgeneem in die Tb nie. Daardie stink ... miskien kan mens verstaan dat Totius dit nie wou gebruik nie, al behou sy Nederlandse voorbeeld dit! Maar daardie wonde wat dra - ook dit was waarskynlik vir Totius nie poëties genoeg nie. Vers 6 in die AOV het dit in die Tb geword:

$\mathrm{Ag}$, hoe lelik is die wonde

Die prosa van Psalm 38 in die AOV het meer poëtiese krag as die gedig in die Tb. Die Afrikaanse prosa van die AOV en die poësie van die $\mathrm{Tb}$ is twee verskillende prestasies van dieselfde skrywer. Teen die verwagting in oortref die prosa die poësie, ook daar waar dit gaan om die liriese as tema in 'n besondere Psalm. Psalm 33 praat van musiekinstrumente en van die liriese lofprysing van God. Totius se prosabewerking in die AOV is ' $n$ baie stemmige maar tog liriese vertaling. Lê ons sy beryming daarnaas, is dit ' $n$ minder stemmige liriek - wat hy nie uit die Bybel (en uit sy eie Bybelvertaling) kry nie, maar weer uit die N1773, of, as mens na die leestekens kyk, uit Van Elring met motiewe wat nie in die Bybel staan nie, gehaal uit die N1773. Ek haal nie breedvoerig aan nie - enigeen kan Psalm 33 in die AOV, die Tb en die N1773 met mekaar vergelyk. Lees mens die teks hiervan in die N1773, hoor jy dadelik die $\mathrm{Tb}$ se ooreenkoms daarmee, en die ooreenkoms tussen die $\mathrm{Tb}$ en die $\mathrm{N} 1773$ is baie sterker is as dié tussen die $\mathrm{Tb}$ en die AOV:

Sing vrolik, hef die stem na bowe; 
regverdiges, verhef die Heer

Zingt vroolijk, heft de stem naar boven;

Rechtvaardigen! Verheft den Heer

In die AOV lui dit eenvoudig:

o Regverdiges, jubel in die Here!

Daar is 'n ander eienaardigheid: Die N1773 se invloed op Totius was so sterk, dat dit nie net die Tb beïnvloed het nie. Totius het dit so goed bekyk, en sekerlik ook so deeglik geken deur voortdurende gebruik, dat dit selfs sy prosavertaling van die Psalms in die AOV hier en daar beïnvloed het, en, soms versterkend!

Psalm 139 is een van die mooistes. Dit is die Psalm van "Die goddelike alwetendheid" - mens sou dit ook kon beskryf as "Die goddelike vooruitwetendheid". Dit beskryf hoe God die mens se gedagtes "van ver" verstaan, nog voor hulle by die mens opkom, en miskien die heel mooiste gedeelte is dié wat die voorgeboortelike lewe beskryf. Van die mooi beskrywings in die AOV van God se wete van die mens het betreklik min tereggekom in die $\mathrm{Tb}$, maar daar is byvoorbeeld een ding wat Totius waarskynlik [net?] in die N1773 teengekom het en wat hy nie net in die $\mathrm{Tb}$ behou het nie maar selfs in die AOV. Dit is daardie woorde in vers 16 :

U oë het my ongevormde klomp gesien

wat in die N1773 lui:

Gij hebt, wijl niets uw oog weerhoudt, mijn ongevormden klomp beschouwd.

Dit is baie beeldryker as die ANV en dalk selfs beter as die vertaling van Ida Gerhardt, wat na my mening nogtans een van die heel beste Psalmvertalings is:

Uw oog zag mij, vormeloos nog

In Psalm 144 van die AOV word daar gebid vir goeie dinge in die land, en dan word in vers 14 gevra dat "ons beeste gelaai mag wees". Dit is 'n onafrikaanse beeld wat in die ANV lui dat "ons beestrop 'n groot kalweroes (mag) lewer". Hierdie gelaai wees van die dragtige diere kry mens weer in die N1773 (strofe 6): 
Ons rundervee zij sterk en wêl geladen

Ten slotte: Daar is wel van sy berymings waar Totius taamlik getrou aan sy taal van die AOV gebly het, maar dit is die uitsonderings. Totius se beiteltaal lề nie, soos mens natuurlikerwys van 'n digter sou verwag, in die Tb nie maar in die AOV. Die Psalms is eintlik (antieke) gedigte, en Totius is eintlik digter, maar die fris, natuurlike prosa van sy Psalmvertalings in die AOV, sober en tewens liries, oortref die Psalms in die digvorm van die $\mathrm{Tb}$ baie ver.

Ek het net die ruimte gehad om met enkele voorbeelde te werk. Daar is talle voorbeelde van die aspekte wat ek hierbo genoem het.

\section{Literatuurverwysings}

De Interkerkelijke Stichting voor de Psalmberijming, 1961. 150 Psalmen. Proeve van een nieuwe berijming. Wageningen: Zomer en Keuning.

Die Nederlandse Bijbel-Compagnie 1933, te Amsterdag, J. Brandt en Zoon, te Haarlem Joh. Enschede en Zonen.

Gerhardt, 1 1994. De Psalmen. Brugge: Tabor.

Ridderbos, J 1955. De Psalmen. Kampen: J H Kok.

Van Elring, G s j: De Psalmen. Gekozen en bewerkt uit vele dichters. Amsterdag:

$\mathrm{P} N$ van Kampen en Zoon.

Afrikaans Nuwe Vertaling 1983.

Afrikaans Ou Vertaling 1933.

Totius 1936. Totius Beryming van die Psalms.

Nederlandse Psalmberyming 1773. 